\title{
Enzymatic Determination of Primary Normal Alcohols as Apparent Ethanol Content in Honey
}

\author{
José F. Huidobro, ${ }^{*}+$ M. Estrella Rea, ${ }^{\dagger}$ Paula C. Branquinho de Andrade, ${ }^{\ddagger}$ M. P. Sánchez, ${ }^{\dagger}$ \\ M. Teresa Sancho, ${ }^{\S}$ Soledad Muniategui," and Jesús Simal-Lozano ${ }^{\dagger}$ \\ Facultad de Farmacia, Area de Nutrición y Bromatología, Universidad de Santiago, \\ 15706 Santiago de Compostela (Galicia), Spain, Facultad de Farmacia, Laboratorio de Farmacognosia, \\ Universidade de Coimbra, Coimbra, Portugal, Facultad de Ciencia y Tecnología de los Alimentos, \\ Area de Nutrición y Bromatología, Universidad de Valladolid, Burgos (Castilla y León), Spain, and \\ Facultad de Ciencias, Area de Química Analítica, Universidad de La Coruña, La Coruña (Galicia), Spain
}

\begin{abstract}
Primary normal alcohols of 33 unpasteurized Galician (northwestern Spain) honeys have been determined as apparent ethanol contents. A modification of the Boehringer-Mannheim enzymatic method has been used. The solution of honey has been employed directly, neither clarified nor neutralized. Removal of interferences required absorbance measurements at $340 \mathrm{~nm}$, by using the solution of honey with the solution of aldehyde dehydrogenase into the reference cuvette. Water is added to the reference cuvette and alcohol dehydrogenase suspension to the sample cuvette. The blanks are measured following the same procedure with redistilled water instead of sample solution. Ten replicate analyses of each of four samples with apparent ethanol levels of 13.5, 35.3, 50.1, and $141.8 \mathrm{mg} / \mathrm{kg}$ gave coefficient of variations of $1.74 \%, 0.48 \%, 0.34 \%$, and $0.22 \%$, respectively. The modified enzymatic method performed well in recovery experiments (recovery 100.1\%). The apparent ethanol contents of 32 of the 33 honeys studied lay in the range $13.5-50.1 \mathrm{mg} / \mathrm{kg}$ (mean $27.8 \mathrm{mg} /$ $\mathrm{kg}$ ); the remaining unspoiled honey had an apparent ethanol content of $141.8 \mathrm{mg} / \mathrm{kg}$.
\end{abstract}

Keywords: Honey; ethanol; alcohols; enzymatic analysis

\section{INTRODUCTION}

It has long been recognized that honey can be spoiled by unintentional fermentation, producing ethanol, carbon dioxide, and volatile and nonvolatile acids (Fabian and Quinet, 1928; Marvin, 1928, 1930; Lochhead and Heron, 1929; Wilson and Marvin, 1929; Lochhead and Farrell, 1930, 1931; Dyce, 1931; Marvin et al., 1931; Wilson and Marvin, 1931, 1932; Lochhead, 1933). The yeasts responsible may come from the body of the bee, from the floor of the hive or the processing room, or from processing equipment (Fabian and Quinet, 1928; Crane, 1975; Comi et al., 1982; Crane, 1990). Small quantities of ethanol are also, however, a natural component of unspoiled honey (Duisberg, 1967), which makes it desirable to know how high such nonpathological levels may be. Surprisingly, the only published information in this area appears to be Borries' (1934) finding that naturally occurring ethanol is equivalent to less than $1 \%$ of the sugar content of the honey.

The first gas chromatographic (GC) separation of ethanol from honey was performed using Carbowax 1500 or polyphenyl ether as stationary phase (Cremer and Riedmann, 1964, 1965). Subsequently, an improved GC method for the determination of volatile honey components was developed which uses acetone for extraction, an OV-1 capillary column, and mass spectrometry (MS) for detection (Bicchi et al., 1983).

Alternatively, kits for the determination of ethanol in various foods, including honey, have been developed

\footnotetext{
* Author to whom correspondence should be addressed.

$\dagger$ Universidad de Santiago.

‡ Universidad de Coimbra.

\& Universidad de Valladolid.

"Universidad de La Coruña.
}

by Boehringer-Mannheim (1989) on the basis of enzymesubstrate reactions. However, the details of the enzymatic method for honey were not optimized by Boehringer-Mannheim, and their validation has not been described in the literature (personal communication).

The purpose of this work has been to determine the apparent ethanol (ethanol, 1-propanol, butanol, and pentanol, among other primary normal alcohols) contents of several unspoiled honeys by applying the Boehringer-Mannheim (1989) enzymatic method. In the literature, we have not found data about apparent ethanol contents of honeys determined by using this method.

\section{MATERIALS AND METHODS}

Samples. We used 33 samples honeys of Galicia (northwestern Spain); 31 honeys were floral honeys, and 2 honeys were a mix of floral and honeydew sources (Huidobro et al., 1993). Microscopic analysis showed that the honeys were unspoiled by yeasts.

Reagents and Apparatus. (a) Boehringer-Mannheim (1989) Enzymatic Test for $3 \times 10$ Determinations (Catalog No. 176 290). The test combination contains the following.

(a1) Potassium Diphosphate Buffer ( $p H$ 9.0) Containing Stabilizers. This solution is used without dilution. It is stable for 1 year at $4{ }^{\circ} \mathrm{C}$. Before use, allow solution to come to room temperature.

(a2) Tablets Containing $4 \mathrm{mg}$ of Nicotinamide Adenine Dinucleotide (NAD), 0.8 IU of Aldehyde Dehydrogenase (Al$D H$ ), and Stabilizers. Dissolve with $3 \mathrm{~mL}$ of (a1) one tablet of (a2). This solution is stable for 1 day at $4{ }^{\circ} \mathrm{C}$. Before use, allow solution to come to room temperature.

(a3) 7000 IU of Alcohol Dehydrogenase ( $A D H)$ in Suspension with Stabilizers. This solution is used without dilution. It is stable for 1 year at $4{ }^{\circ} \mathrm{C}$.

(a4) $0.058 \mathrm{~g} / L$ Ethanol Standard Solution. 


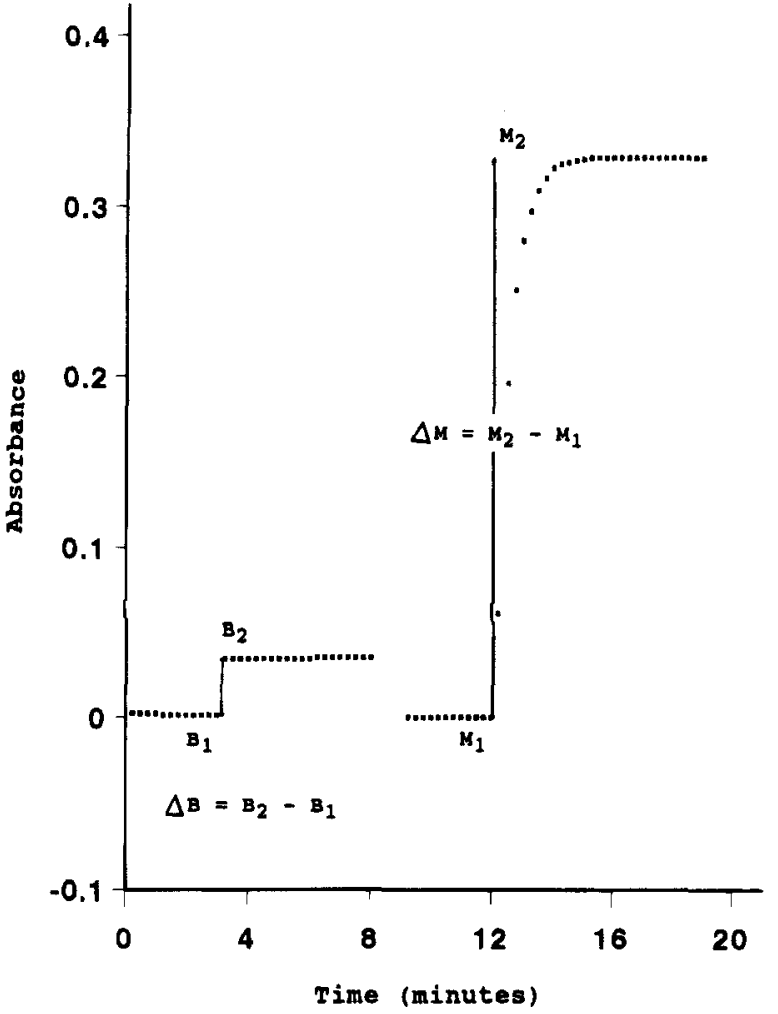

Figure 1. Absorbances at $340 \mathrm{~nm}$ measured to determine ethanol in honey using the enzymatic method.

(b) A Hitachi 100-60 UV-vis double-beam spectrophotometer was used.

Procedure. Sample Solution. Dissolve $5 \mathrm{~g}$ of honey with water and transfer to a $50-\mathrm{mL}$ flask and make up to mark with water.

Spectrophotometry Measurements at $340 \mathrm{~nm}$. Dissolve 1 NAD tablet (a2) in $3 \mathrm{~mL}$ of potassium diphosphate buffer (a1), divide equally $(1.5 \mathrm{~mL})$ between two quartz spectrophotometer cuvettes ( $2 \mathrm{~mL}$ and $1 \mathrm{~cm}$ light path). Then add $0.250 \mathrm{~mL}$ of sample solution to each cuvette, stir, and obtain the absorbance difference at $340 \mathrm{~nm}\left(M_{1}\right)$ when stable (after approximately 3 $\mathrm{min}$ ). Then add $0.025 \mathrm{~mL}$ of water to the reference cuvette and $0.025 \mathrm{~mL}$ of enzyme suspension (a3) to the sample cuvette, stir, and obtain the absorbance difference at $340 \mathrm{~nm}\left(M_{2}\right)$ when stable (after approximately 5-10 min). Repeat the whole procedure with blanks in which sample solution has been replaced by the same volume of double-distilled water; obtain absorbance differences $B_{1}$, corresponding to $M_{1}$, and $B_{2}$, corresponding to $M_{2}$ (Figure 1).

Calculations. For honey, following our procedure, the apparent ethanol content is calculated as follows (BoehringerMannheim, 1989):

$\mathrm{mg}$ of apparent ethanol/kg of honey $=$

$$
\frac{1298}{\text { sample wt in } \mathrm{g}} \times\left(A_{\text {sample }}-A_{\text {blank }}\right)
$$

The factor of

$$
1298=\frac{1.775 \times 46.07}{6.30 \times 1 \times 0.250 \times 2 \times 1000} \times \frac{50}{1000} \times 1000 \times 1000
$$

In these equations $A_{\text {sample }}$ is the absorption of the sample, $A_{\text {blank }}$ is the absorption of the blank, $1.775=$ final volume $(\mathrm{mL}), 46.07$ $=$ mol wt of ethanol, $6.30=$ absorption coefficient of $\mathrm{NADH}$ at $\mathrm{Hg} 340 \mathrm{~nm}\left(\mathrm{~L} \mathrm{mmol}{ }^{-1} \mathrm{~cm}^{-1}\right), 1=$ light path $(\mathrm{cm}), 0.250=$ sample volume $(\mathrm{mL}), 2=$ the quantity of $\mathrm{NADH}$ obtained is equivalent to the half of the ethanol quantity, $1000=\mathrm{mL}$ in $1 \mathrm{~L},(50 / 1000)=\mathrm{g}$ of apparent ethanol in $50 \mathrm{~mL}$ of final solution, $1000=\mathrm{mg}$ in $1 \mathrm{~g}$, and $1000=\mathrm{g}$ in $1 \mathrm{~kg}$.
Table 1. Study of the Precision of the Enzymatic Method To Determine Apparent Ethanol (Milligrams per Kilogram) in Honey

\begin{tabular}{lcccc}
\hline & sample 8 & sample 7 & sample 1 & sample 25 \\
\hline mean & 13.5 & 35.3 & 50.1 & 141.8 \\
$\mathrm{SD}^{a}$ & 0.2348 & 0.1729 & 0.1703 & 0.3127 \\
$\mathrm{CV}^{b}$ & 1.74 & 0.48 & 0.34 & 0.22
\end{tabular}

${ }^{a} \mathrm{SD}$, standard deviation. ${ }^{b} \mathrm{CV} \%$, coefficient of variation percent.

Table 2. Study of the Recovery of the Enzymatic Method To Determine Apparent Ethanol (Milligrams per Kilogram) in Honey

\begin{tabular}{lccc}
\hline present & added & found & recovery, \% \\
\hline & 10 & 16.7 & 99.0 \\
& 10 & 16.8 & 100.0 \\
& 10 & 16.7 & 99.0 \\
& 30 & 36.8 & 100.0 \\
& 30 & 36.7 & 99.7 \\
6.8 & 30 & 36.8 & 100.0 \\
& & & \\
& 50 & 56.9 & 100.2 \\
& 50 & 56.9 & 100.2 \\
& 50 & 56.7 & 99.8 \\
& 150 & 157.4 & 100.4 \\
& 150 & 157.9 & 100.7 \\
mean & 150 & 159.7 & 101.9 \\
SD $^{a}$ & & & 12 \\
CV $^{b}$ & & & 100.1 \\
SD & & & 0.763 \\
& & & 0.76
\end{tabular}

${ }^{a} \mathrm{SD}$, standard deviation. ${ }^{b} \mathrm{CV} \%$, coefficient of variation percent.

\section{RESULTS}

Repeatability. From each of 4 (samples 8, 7, 1, and 25) unspoiled honeys with low $(13.5 \mathrm{mg} / \mathrm{kg})$, medium $(35.3 \mathrm{mg} / \mathrm{kg})$, high $(50.1 \mathrm{mg} / \mathrm{kg})$, and very high $(141.8$ $\mathrm{mg} / \mathrm{kg}$ ) apparent ethanol contents, 10 samples were taken for apparent ethanol determination as above. The greatest coefficient of variation (that of the low apparent ethanol honey) was $1.74 \%$ (Table 1 ).

Recovery. Samples of a honey containing $6.8 \mathrm{mg} /$ $\mathrm{kg}$ of apparent ethanol were fortified with various amounts of apparent ethanol (the reference solution of the Boehringer-Mannheim kit) to cover the concentration range present in the samples analyzed (approximately $10-150 \mathrm{mg} / \mathrm{kg}$ ), and the apparent ethanol contents of the fortified samples were determined. Mean recovery was $100.1 \%$, with a coefficient of variation of $0.76 \%$ (Table 2).

Specificity. Included in the "apparent ethanol concentration" determined as above are the concentrations of all the other linear primary alcohols except methanol, though ethanol is the major contributor (Cremer and Riedmann, 1964, 1965). Nonlinear alcohols do not contribute significantly, and secondary, tertiary, and aromatic alcohols are not susceptible to the enzymes used in this method. Even high concentrations of glycerol (more than $400 \mathrm{mg} / \mathrm{kg}$ ) in honey (Laub and Marx, 1987) do not cause significant interferences (Boehringer-Mannheim, 1989).

Apparent Ethanol Contents of the Galician Honeys Analyzed. The apparent ethanol contents of the 33 Galician honeys analyzed ranged from 13.5 to 141.8 $\mathrm{mg} / \mathrm{kg}$. If the sample containing $141.8 \mathrm{mg} / \mathrm{kg}$ is excluded, the sample with the highest apparent ethanol 
Table 3. Apparent Ethanol Contents of the Honeys Analyzed

\begin{tabular}{cccc}
\hline sample & $\begin{array}{c}\text { apparent } \\
\text { ethanol, } \mathbf{m g} / \mathbf{k g}\end{array}$ & sample & $\begin{array}{c}\text { apparent } \\
\text { ethanol, } \mathbf{m g} / \mathbf{k g}\end{array}$ \\
\hline 1 & 50.1 & 20 & 24.9 \\
2 & 44.2 & 21 & 25.6 \\
3 & 41.9 & 22 & 36.7 \\
4 & 31.7 & 23 & 15.0 \\
5 & 30.5 & 24 & 26.1 \\
6 & 26.5 & 25 & 141.8 \\
7 & 35.3 & 26 & 42.4 \\
8 & 13.5 & 27 & 23.1 \\
9 & 25.5 & 28 & 13.6 \\
10 & 23.2 & 29 & 15.4 \\
11 & 35.3 & 30 & 18.7 \\
12 & 13.5 & 31 & 16.4 \\
13 & 29.2 & 32 & 23.7 \\
14 & 32.2 & 33 & 41.0 \\
15 & 35.8 & & \\
16 & 32.0 & mean & 31.3 \\
17 & 31.9 & SD & 22.2 \\
18 & 15.7 & $V_{\min }$ & 13.5 \\
19 & 19.0 & $V_{\max }$ & 141.8 \\
SD, standard deviation. & & \\
& & &
\end{tabular}

content had $50.1 \mathrm{mg} / \mathrm{kg}$ of apparent ethanol (Table 3). Mean concentration was $31.3 \mathrm{mg} / \mathrm{kg}(27.8 \mathrm{mg} / \mathrm{kg}$ if the high outlier is excluded).

\section{DISCUSSION}

The procedure laid down by Boehringer-Mannheim (1989) for preparation of honey samples prior to determination of apparent ethanol with their enzymatic kit is as follows: dissolve $20 \mathrm{~g}$ of honey with water, make up to $100 \mathrm{~mL}$ of water, transfer $10 \mathrm{~mL}$ of this solution to a $25-\mathrm{mL}$ volumetric flask, add Carrez solutions I [3.60 $\mathrm{g}$ of $\mathrm{K}_{4} \mathrm{Fe}(\mathrm{CN})_{6} \cdot 3 \mathrm{H}_{2} \mathrm{O} / 100 \mathrm{~mL}$ of water] and II $(7.20 \mathrm{~g}$ of $\mathrm{ZnSO}_{4} \cdot 7 \mathrm{H}_{2} \mathrm{O} / 100 \mathrm{~mL}$ of water) to clarify, neutralize with $\mathrm{NaOH}$ solution, make up to $25 \mathrm{~mL}$ with water, and stir.

When applied to our samples of unfermented honey, which had apparent ethanol contents in the range 13.5$141.8 \mathrm{mg} / \mathrm{kg}$, the quantity of apparent ethanol in $0.5 \mathrm{~mL}$ of final solution is $0.54-5.67 \mu \mathrm{g}$, well within the range recommended by Boehringer-Mannheim (0.5-12.0 $\mu \mathrm{g}$ in $0.1-0.5 \mathrm{~mL}$ ). In spite of this, determination of apparent ethanol according to the Boehringer-Mannheim (1989) method proved to be impossible because absorbance differences-time (the absorbance differences are with respect to blank cuvettes containing water) failed to recover the same slope after addition of the alcohol dehydrogenase as before.

Attempts to overcome this problem by reversing the order of clarification and neutralization or by changing the concentrations of $\mathrm{NaOH}$ and/or Carrez solutions all met with failure.

It was therefore decided to use a pair of controls in which alcohol dehydrogenase was replaced by water. The absorbance differences obtained when sample plus enzyme was run against sample plus water and water plus enzyme against water plus water (the procedure described under Material and Methods) stabilized satisfactorily, allowing unequivocal readings to be taken.

In addition, we observed that previous clarification and neutralization were not necessary. The buffer of the enzymatic test provides the appropiate $\mathrm{pH}$ for the determination.

In conclusion, the Boehringer-Mannheim method for enzymatic determination of ethanol in foods was modi- fied to allow precise determination of the apparent ethanol content of unspoiled honey. In the modified method interferences are taken into account by running $\mathrm{ADH}$-free control solutions against sample and blank; neither clarification nor neutralization of the sample is required. The method is sufficiently precise, interference-free, simple, and inexpensive for practical application.

The apparent ethanol contents of 33 honeys of Galicia (northwestern Spain) lay in the range 13.5-141.8 mg/ $\mathrm{kg}$ (mean $31.3 \mathrm{mg} / \mathrm{kg}$ ), with 32 of them in the range $13.5-50.1 \mathrm{mg} / \mathrm{kg}$ (mean $27.8 \mathrm{mg} / \mathrm{kg}$ ).

\section{ACKNOWLEDGMENT}

We thank Prof. Juan Carlos García Monteagudo, Departamento de Fisico-Química; Profs. Oscar García Martín and José Luis Sánchez López, Departamento de Bioquímica; Profs. José Sordo Rodríguez and Alfonso Castiñeiras Campos, Departamento de Química Inorgánica; and Prof. Tomás González Villa, Departamento de Microbiología, all of the Pharmacy Faculty of the University of Santiago de Compostela, for helpful comments and material. We also thank the various honey producers who provided samples. P.C.B.A. thanks Junta Nacional de Investigaçáo Científica e Tecnologica (JNICT) for a grant. Finally, we thank the Consellería de Agricultura, Ganadeiria e Montes of the Xunta de Galicia, who funded this study through the Producto Galego de Calidade-Mel de Galicia scheme.

\section{LITERATURE CITED}

Bicchi, C.; Belliardo, F.; Frattini, C. Identification of the volatile components of some Piedmontese honeys. J. Apic. Res. 1983, 22, 130-6.

Boehringer-Mannheim GmbH. "Biochemical food analysis. Ethanol", ref 176 290; Mannheim, Germany, 1989.

Borries, G. Reactions during the fermentation of honey. $Z$. Unters. Lebensm. 1934, 67, 65-75.

Comi, G.; Beretta, G.; Traldi, C. Microbial spoilage of honey. Ristorazione Collettiva 1982, 7, 116-8.

Crane, E. Honey: A Comprehensive Survey; Heinemann: London, 1975.

Crane, E. Bees and Beekeeping; Heinemann: Oxford, U.K., 1990.

Cremer, E.; Riedmann, M. Identification of the gas-chromatographically separated aromatic materials of honey. $Z$. Naturfosch. 1964, 19B, 76-7.

Cremer, E.; Riedmann, M. Gas chromatographic Examination of the Question of Honey Aromas. Monatsh. Chem. 1965, $96,364-8$.

Duisberg, H. Honey and Unspoiled Honey. Handb. Lebensmittelchem. 1967, 5, 491-559.

Dyce, E. J. Fermentation and crystallization of honey and heating of crystallized honey. Bee World 1931, 13, 14-8.

Fabian, F. W.; Quinet, R. I. A study of the cause of honey fermentation. Bull. Mich. Agric. Coll. Exp. Stn. 1928, 62.

Huidobro, J. F.; Rea, M. E.; Branquinho de Andrade, P. C.; Sancho, M. T.; Muniategui, S.; Simal-Lozano, J. Enzymatic Determination of Glycerol in Honey. J. Agric. Food Chem. 1993, 41, 557-9.

Laub, E.; Marx, R. Glycerin, a natural ingredient of honey. Lebensmittelchem. Gerichtl. Chem. 1987, 41, 110.

Lochhead, A. G. Factors concerned with the fermentation of honey. Zentralbl. Bakteriol., Parasitenkd, Infektionskrankh. Hyg., Abt. 2 1933, 88, 296-302.

Lochhead, A. G.; Farrell, L. Soil as a source of infection of honey by sugar-tolerant yeasts. Can. J. Res. 1930, 3, 5164. 
Lochhead, A. G.; Farrell, L. The types of osmophilic yeasts found in normal honey and their relation to fermentation. Can. J. Res. 1931, 5, 665-72.

Lochhead, A. G.; Heron, D. A. Microbiological studies of honey. I. Honey fermentation and its cause. II. Infection of honey by sugar-tolerant yeasts. Bull. Can. Dep. Agric. 1929, 116, $47 \mathrm{pp}$.

Marvin, G. E. The occurrence and characteristics of certain yeasts found in fermented honey. J. Econ. Entomol. 1928, $21,363-70$.

Marvin, G. E. Further observations on the deterioration and spoilage of honey in storage. J. Econ. Entomol. 1930, 23, $431-8$.

Marvin, G. E.; Peterson, W. H.; Fred, E. B.; Wilson, H. F. Some of the characteristics of yeasts found in fermenting honey. J. Agric. Res. 1931, 43, 121-31.
Wilson, H. F.; Marvin, G. E. On the occurrence of the yeasts which may cause the spoilage of honey. J. Econ. Entomol. 1929, 22, 513-7.

Wilson, H. F.; Marvin, G. E. The effect of temperature on honey in storage. J. Econ. Entomol. 1931, 24, 589-97.

Wilson, H. F.; Marvin, G. E. Relation of temperature to the deterioration of honey in storage. A progress report. J. Econ. Entomol. 1932, 25, 525-8.

Received for review December 16, 1993. Revised manuscript received April 18, 1994. Accepted June 16, 1994. ${ }^{\otimes}$

Q Abstract published in Advance ACS Abstracts, August 1, 1994. 